\title{
EFFECT OF SOME ORGANIC, CHEMICAL AND BIOFERTILIZERS ON GARLIC (Allium sativum L.):
}

1- Cattle manure

El - Gazar, T. M. * ; H. M. Abd El - Naby *; A. M. Abd El-Hamed**;

A. S. El-Gamal* and A. E. S. Abd El-Kader**

* Veget. And Flori. Dept., Fac. of Agric., Mansoura Univ.

${ }^{* *}$ Veget. Dep. Hort. Res. Institute, Agric. Res. Center.

\begin{abstract}
Two experiments were carried out on garlic clone Sids 40 , in the vegetable private farm at Tawila village Dakahlia Governorate during the two successive seasons of $2003 / 2004$ and $2004 / 2005$ to study the effect of two cattle manure levels

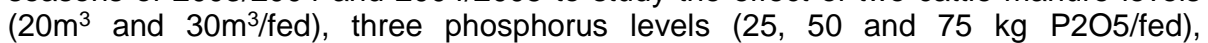
phosphorien (with $3 \mathrm{~kg} / \mathrm{fed}$ and without) and potassium fertilization (soil fertilization 72 $\mathrm{kg} \mathrm{K} 2 \mathrm{O} / \mathrm{fed}$ and $60 \mathrm{~kg} \mathrm{~K} 2 \mathrm{O} / \mathrm{fed}+1 \% \mathrm{~K}_{2} \mathrm{O} / \mathrm{fed}$ as foliar fertilization) on growth, yield and its components, chemical composition and storability of garlic.

The results indicated that treatment of $30 \mathrm{~m}^{3} / \mathrm{fed}$ cattle manure $+50 \mathrm{~kg} \mathrm{P} \mathrm{P}_{2} \mathrm{O}_{5} / \mathrm{fed}$ + with phosphorien $(3 \mathrm{~kg} / \mathrm{fed})+60 \mathrm{~kg} \mathrm{~K} \mathrm{~K}_{2} \mathrm{O} / \mathrm{fed}+1 \% \mathrm{~K}_{2} \mathrm{O} / \mathrm{fed}$ foliar fertilization gave the best results for (fresh weight/plant, dry weight /plant, leaf area/plant, diameter of bulb at 160 days after planting, weight of bulb, bulb yield/fed, N, P and K percentage and total chlorophyll content) during the two seasons. But, it had the lowest values of bulbing ratio at 120 and 160 days after planting at the two seasons, the same treatment had the lowest value of weight of loss percentage of bulbs in the second season. While the treatment of $30 \mathrm{~m}^{3} / \mathrm{fed}$ cattle manure $+75 \mathrm{~kg} \mathrm{P}_{2} \mathrm{O}_{5} / \mathrm{fed}+$ with phosphorien $+60 \mathrm{~kg} \mathrm{~K} \mathrm{~K}_{2} \mathrm{O} / \mathrm{fed}+1 \% \mathrm{~K}_{2} \mathrm{O} / \mathrm{fed}$ foliar fertilization gave lowest value of weight of loss percentage of bulbs in the first season.

Therefore, the treatment of $30 \mathrm{~m}^{3} / \mathrm{fed}$ cattle manure $+50 \mathrm{~kg} \mathrm{P} \mathrm{P}_{5} / \mathrm{fed}+$ with phosphorien ( $3 \mathrm{~kg} / \mathrm{fed})+60 \mathrm{~kg} \mathrm{~K} 2 \mathrm{O} / \mathrm{fed}+1 \% \mathrm{~K}_{2} \mathrm{O} / \mathrm{fed}$ foliar fertilization could be recommended for raising garlic yield with good quality bulbs.
\end{abstract}

\section{INTRODUCTION}

Garlic (Allium sativum L.), is one of the most important bulb vegetable crops and is next to onion in importance. It is commonly used as a spice or in the medicinal purposes. In Egypt, it has been generally cultivated for both local consumption and export.

The importance of using organic fertilizer decrease using chemical fertilizer in plant production is one of the important ways in health protection. Organic manure serve two purposes in soil, its supply both major and minor nutrients for plant and microorganisms. It also improve the physical conditions in soil (Cook 1972 and 1982).

Several investigators reported that the application of (organic manure) i.e. cattle manure increase the vegetative growth, yield and its components, NPK content and storability ( El-Mansi et al. (1999), Abou El-Magd et al. (2003), Patil et al. (2005), Yassen and Khalid (2009).

El-Mansi et al. (1999) under sandy soil conditions, found that adding 20 or $40 \mathrm{~m}^{3} \mathrm{FYM} / \mathrm{fed}$ significantly increased chlorophyll $\mathrm{a}, \mathrm{b}$, total $(\mathrm{a}+\mathrm{b})$ and carotenoids in leaf tissues of pea plants. Abou El-Magd et al. (2003) indicated that higher vegetative growth (plant height, number of leaves and fresh 
weight of plants) was obtained by cattle manure or mineral fertilization on garlic. El-Mansi et al. (2004) worked on garlic, they found that addition of 45 $\mathrm{m}^{3} \mathrm{FYM} / \mathrm{fed}$ recorded maximum values of yield of both first and second grades, total and marketable yield as well as average bulb weight. And N, P and $\mathrm{K}$ content in cloves. Patil et al. (2005) showed that with the increasing level of FLY ash and FYM there was a corresponding increase in the up take of nitrogen, phosphorus and potassium of onion. Yassen and Khalid (2009) on onion, found that all organic fertilizer treatments is mixture of farmyard treatment (recommended NPK) and improved the vegetative growth, essential oil and NPK content.

Phosphorus is considered the second essential nutrient element for plant growth and development, it plays an important role in certain prevalent steps in plant growth, such as accumulation and release of energy celluar metabolism, in addition, it is main constituent of many organic compounds in plant (Russell, 1950). Several researchers reported that P-nutrient is very important for garlic plant growth. Setty et al. (1989) showed that $P$ fertilization was needed for garlic plant growth and development. They added that application of $\mathrm{P}(0,50$ and $100 \mathrm{~kg} / \mathrm{ha})$ progressively increased the number of leaves/plant, neck thickness and shoot dry matter. In general, the results indicated that application of $\mathrm{P}$ fertilizers exerted apparent increases in plant growth of garlic or onion viz. number of leaves, foliage fresh and dry weight as well as bulbing ratio, bulb yield/fed, its components, bulb weight, dry matter and NPK contents El-Kalla et al. (1997), Abd El-Rehim (2000), Jakse and Mihelic (2001), Turk and Tawaha (2001), Muthuramalingam et al.(2002) and Lee-Jong Tae et al. (2003).

Lee-Jong Tae et al. (2003) found that on onion leaves chlorophyll content increased with increasing $\mathrm{N}$ rate. $\mathrm{P}_{2} \mathrm{O}_{5}$ at $80 \mathrm{~kg} / \mathrm{ha}$ recorded that highest chlorophyll content $(0.47 \mathrm{mg} / \mathrm{kg})$ compared with the other rates of the same fertilizer, total yield, marketable bulbs and yield components was significantly increased with increasing phosphorus level up to $60 \mathrm{~kg} \mathrm{P}_{2} \mathrm{O}_{5}$ or $75 \mathrm{P}_{2} \mathrm{O}_{5} / \mathrm{fed}$ Santhi et al. (2005) found that nutrient uptake increased with increasing rates of $\mathrm{N}, \mathrm{P}$ and $\mathrm{K}$ in combination.

Phosphorien content Bacillus megatherium a phosphate dissolving bacteria. Many investigators reported that application of phosphobacterium are involved in the availability of phosphorus and other elements in soils, through the decomposition of organic compounds, which may lead to a change in the soil reaction (Mahmoud and Abdel-Hafez, 1982; Forster and Freter, 1988 and El-Dahtory et al. (1989).

El-Sheekh (1997) found that the highest values of dry weight/plant, total yield/fed, diameter of bulb and weight bulb of onion plant were obtained by adding phosphorien at $400 \mathrm{gm} / \mathrm{fed}$ El-Kalla et al. (1999) reported that application of biophosphatic fertilizer (phosphorien) to onion plants at 400 $\mathrm{g} / \mathrm{fed}$ resulted an increase in number of leaves/plant as well as fresh and dry weight/plant over the uninoculated treatment moreover, phosphorien application increased neck thickness, gave best bulbing ratio, total yield/fed and bulb quality.

Several investigators reported that the application of phosphorien or mycorrhizae (VAM) increase the vegetative growth, yield and its components, 
N, P and K contents and storability on garlic or onion plants. (Al-Karaki, 2002; Alok-Singh et al., 2002; Sari et al., 2002; El-Shaikh, 2005 and Jha et al., 2006).

Potassium element is very important in over all metabolism of plant enzymes activity, it was found to serve a vital role in a photosynthesis by direct increasing in growth, leaf area and hence $\mathrm{Co}_{2}$ assimilation potassium also has a beneficial effect of water consumption. (Mengel and Kirkby, 1982; Gardener et al., 1985; Abd El-Aal, 1990 and Said, 1997).

Foliar fertilization of potassium is more economical than root application due to the higher degree of applied nutrients utilization and the continuous increases in the costs of using chemical fertilizers (Franke, 1986).Ciecko et al. (2000) showed that increasing of the K rate significantly increased total chlorophyll biosynthesis in potato leaves. El-Morsy et al. (2004) on garlic, found that plant height, shoot dry weight/plant, bulbing ratio, total yield, bulb weight, bulb diameter, number of cloves and clove weight in both seasons only were significantly increased with supply $50 \% \mathrm{~K}$ fertilizer as a soil application and foliar application $2 \% \mathrm{~K}_{2} \mathrm{O}$ solution in comparison with other treatment. Also, increased concentration of N, P, K and increasing of the storability of garlic plants. Similar results were obtained by Nikardi (2009) on potato and Shaheen et al. (2009) on pea plants.

\section{MATERIALS AND METHODS}

Two filed experiments were carried out at Tawila Village Dakahlia Governorate during two successive seasons (2003/2004 and 2004/2005) on garlic cultivar sids-40 to study the effect of two levels cattle manure, three phosphorus levels, phosphorien and potassium fertilization on growth, yield and its components, chemical composition and storability of garlic. The soil of the experimental field was clay loam in texture with organic matter\% $(1.95$, 1.88), EC $3.7 \mathrm{ds} / \mathrm{cm}, \mathrm{PH} 7.7$ Available N, P and K contents were 50-70, 10-12 and $330-390 \mathrm{ppm}$ during the first and second seasons.

Cattle manure was added at levels of 20 and $30 \mathrm{~m}^{3} /$ fed it was broadcasted during soil preparation and phosphorus fertilizer with three rates at 25, 50 and $75 \mathrm{~kg} \mathrm{P}_{2} \mathrm{O}_{5} /$ fed in two equal doses (30 and 60 days after planting). Phosphorus was used in the form of super-phosphate (15.5\% $\mathrm{P}_{2} \mathrm{O}_{5}$ ). Phosphorien was mixed with wet cloves at rate of $3 \mathrm{~kg} / \mathrm{fed}$ before planting. Nitrogen fertilizer was used as Ammonium- Sulfate $(20.5 \% \mathrm{~N})$ at the rate of $120 \mathrm{~kg} / \mathrm{fed}$ in two equal doses (30 and 60 days after planting). Potassium fertilizer as Potassium Sulfate $\left(48 \% \mathrm{~K}_{2} \mathrm{O}\right)$, it used two form soil fertilization $72 \mathrm{kgK}{ }_{2} \mathrm{O} / \mathrm{fed}$ and soil fertilization $60 \mathrm{~kg} \mathrm{~K} \mathrm{~K}_{2} \mathrm{O} / \mathrm{fed}+1 \% \mathrm{~K}_{2} \mathrm{O} / \mathrm{fed}$ foliar spray fertilization.

Soil application was applied for two equal times 30 and 60 days later after planting while, foliar application was spared at 50, 70 and 90 days after planting. The experimental design was randomized complete block design with three replicates in these experimental. 


\section{El - Gazar, T. M. et al.}

Treatments of experimental.

1- $20 \mathrm{~m}^{3} /$ fed cattle manure+25 $\mathrm{kg} \mathrm{P} \mathrm{P}_{2} / \mathrm{fed}+$ without phosphorien $+72 \mathrm{~kg}$ $\mathrm{K} 2 \mathrm{O} / \mathrm{fed}$

2- $20 \mathrm{~m}^{3} / \mathrm{fed}$ cattle manure $+25 \mathrm{~kg} \mathrm{P} \mathrm{P}_{5} / \mathrm{fed}+$ without phosphorien $+(60 \mathrm{~kg}$ $\mathrm{K}_{2} \mathrm{O} / \mathrm{fed}+1 \% \mathrm{~K}_{2} \mathrm{O}$ foliar application).

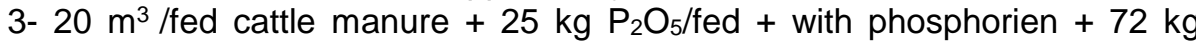
$\mathrm{K}_{2} \mathrm{O} / \mathrm{fed}$

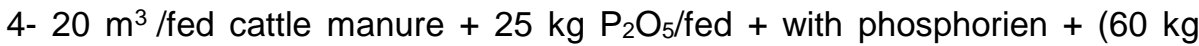
$\mathrm{K}_{2} \mathrm{O} / \mathrm{fed}+1 \% \mathrm{~K}_{2} \mathrm{O}$ foliar application).

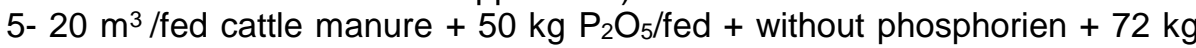
$\mathrm{K}_{2} \mathrm{O} / \mathrm{fed}$

6- $20 \mathrm{~m}^{3} / \mathrm{fed}$ cattle manure $+50 \mathrm{~kg} \mathrm{P}_{2} \mathrm{O}_{5} / \mathrm{fed}+$ without phosphorien $+(60 \mathrm{~kg}$ $\mathrm{K}_{2} \mathrm{O} / \mathrm{fed}+1 \% \mathrm{~K}_{2} \mathrm{O}$ foliar application).

7- $20 \mathrm{~m}^{3} / \mathrm{fed}$ cattle manure $+50 \mathrm{~kg} \mathrm{P} \mathrm{O}_{5} / \mathrm{fed}+$ with phosphorien $+72 \mathrm{~kg}$ $\mathrm{K}_{2} \mathrm{O} / \mathrm{fed}$

8- $20 \mathrm{~m}^{3} / \mathrm{fed}$ cattle manure $+50 \mathrm{~kg} \mathrm{P} \mathrm{O}_{5} / \mathrm{fed}+$ with phosphorien $+(60 \mathrm{~kg}$ $\mathrm{K}_{2} \mathrm{O} / \mathrm{fed}+1 \% \mathrm{~K}_{2} \mathrm{O}$ foliar application).

9- $20 \mathrm{~m}^{3} / \mathrm{fed}$ cattle manure $+75 \mathrm{~kg} \mathrm{P}_{2} \mathrm{O}_{5} / \mathrm{fed}+$ without phosphorien $+72 \mathrm{~kg}$ $\mathrm{K}_{2} \mathrm{O} / \mathrm{fed}$

10- $20 \mathrm{~m}^{3} / \mathrm{fed}$ cattle manure $+75 \mathrm{~kg} \mathrm{P} \mathrm{O}_{5} / \mathrm{fed}+$ without phosphorien $+(60 \mathrm{~kg}$ $\mathrm{K}_{2} \mathrm{O} / \mathrm{fed}+1 \% \mathrm{~K}_{2} \mathrm{O}$ foliar application).

11- $20 \mathrm{~m}^{3} / \mathrm{fed}$ cattle manure $+75 \mathrm{~kg} \mathrm{P} \mathrm{O}_{5} / \mathrm{fed}+$ with phosphorien $+72 \mathrm{~kg}$ $\mathrm{K}_{2} \mathrm{O} / \mathrm{fed}$

12- $20 \mathrm{~m}^{3} / \mathrm{fed}$ cattle manure $+75 \mathrm{~kg} \mathrm{P} \mathrm{P}_{5} / \mathrm{fed}+$ with phosphorien $+(60 \mathrm{~kg}$ $\mathrm{K}_{2} \mathrm{O} / \mathrm{fed}+1 \% \mathrm{~K}_{2} \mathrm{O}$ foliar application).

13- $30 \mathrm{~m}^{3} / \mathrm{fed}$ cattle manure $+25 \mathrm{~kg} \mathrm{P} \mathrm{P}_{5} / \mathrm{fed}+$ without phosphorien $+72 \mathrm{~kg}$ $\mathrm{K}_{2} \mathrm{O} / \mathrm{fed}$

14- $30 \mathrm{~m}^{3} / \mathrm{fed}$ cattle manure $+25 \mathrm{~kg} \mathrm{P} 2 \mathrm{O}_{5} / \mathrm{fed}+$ without phosphorien $+(60 \mathrm{~kg}$ $\mathrm{K}_{2} \mathrm{O} / \mathrm{fed}+1 \% \mathrm{~K}_{2} \mathrm{O}$ foliar application).

15- $30 \mathrm{~m}^{3} / \mathrm{fed}$ cattle manure $+25 \mathrm{~kg} \mathrm{P} \mathrm{O}_{5} / \mathrm{fed}+$ with phosphorien $+72 \mathrm{~kg}$ $\mathrm{K}_{2} \mathrm{O} / \mathrm{fed}$

16- $30 \mathrm{~m}^{3} / \mathrm{fed}$ cattle manure $+25 \mathrm{~kg} \mathrm{P} \mathrm{P}_{5} / \mathrm{fed}+$ with phosphorien $+(60 \mathrm{~kg}$ $\mathrm{K}_{2} \mathrm{O} / \mathrm{fed}+1 \% \mathrm{~K}_{2} \mathrm{O}$ foliar application).

17- $30 \mathrm{~m}^{3} / \mathrm{fed}$ cattle manure $+50 \mathrm{~kg} \mathrm{P} \mathrm{P}_{5} / \mathrm{fed}+$ without phosphorien $+72 \mathrm{~kg}$ $\mathrm{K}_{2} \mathrm{O} / \mathrm{fed}$

18- $30 \mathrm{~m}^{3} / \mathrm{fed}$ cattle manure $+50 \mathrm{~kg} \mathrm{P} \mathrm{O}_{5} / \mathrm{fed}+$ without phosphorien $+(60 \mathrm{~kg}$ $\mathrm{K}_{2} \mathrm{O} / \mathrm{fed}+1 \% \mathrm{~K}_{2} \mathrm{O}$ foliar application).

19- $30 \mathrm{~m}^{3} / \mathrm{fed}$ cattle manure $+50 \mathrm{~kg} \mathrm{P} \mathrm{O}_{5} / \mathrm{fed}+$ with phosphorien $+72 \mathrm{~kg}$ $\mathrm{K}_{2} \mathrm{O} / \mathrm{fed}$

20- $30 \mathrm{~m}^{3} / \mathrm{fed}$ cattle manure $+50 \mathrm{~kg} \mathrm{P}_{2} \mathrm{O}_{5} / \mathrm{fed}+$ with phosphorien $+(60 \mathrm{~kg}$ $\mathrm{K}_{2} \mathrm{O} / \mathrm{fed}+1 \% \mathrm{~K}_{2} \mathrm{O}$ foliar application).

21- $30 \mathrm{~m}^{3} / \mathrm{fed}$ cattle manure $+75 \mathrm{~kg} \mathrm{P} \mathrm{O}_{5} / \mathrm{fed}+$ without phosphorien $+72 \mathrm{~kg}$ $\mathrm{K}_{2} \mathrm{O} / \mathrm{fed}$

22- $30 \mathrm{~m}^{3} / \mathrm{fed}$ cattle manure $+75 \mathrm{~kg} \mathrm{P} \mathrm{O}_{5} / \mathrm{fed}+$ without phosphorien $+(60 \mathrm{~kg}$ $\mathrm{K}_{2} \mathrm{O} / \mathrm{fed}+1 \% \mathrm{~K}_{2} \mathrm{O}$ foliar application).

23- $30 \mathrm{~m}^{3} / \mathrm{fed}$ cattle manure $+75 \mathrm{~kg} \mathrm{P}_{2} \mathrm{O}_{5} / \mathrm{fed}+$ with phosphorien $+72 \mathrm{~kg}$ $\mathrm{K}_{2} \mathrm{O} / \mathrm{fed}$ 
24- $30 \mathrm{~m}^{3} / \mathrm{fed}$ cattle manure $+75 \mathrm{~kg} \mathrm{P} \mathrm{O}_{5} / \mathrm{fed}+$ with phosphorien $+(60 \mathrm{~kg}$ $\mathrm{K}_{2} \mathrm{O} / \mathrm{fed}+1 \% \mathrm{~K}_{2} \mathrm{O}$ foliar application).

NPK percentages of cattle manure used were $0.69 \% \mathrm{~N}, 0.31 \% \mathrm{P}$ and $1.08 \% \mathrm{~K}$.

Garlic cloves were selected uniformly in shape and size. The cloves were planted on the $12^{\text {th }}$ and $9^{\text {th }}$ of October in the first and second seasons, respectively. The cloves were planted on both sides of each ridge at $10 \mathrm{~cm}$ apart. The plot area was $11.2 \mathrm{~m}^{3}$, which contained 4 rides, with $4 \mathrm{~m}$ length and $0.7 \mathrm{~m}$ width.

The harvest was done 180 days after planting for both seasons. The following characters were determined:-

\section{A. Vegetative growth characters}

Five plants from each plot were chosen randomly in both seasons after 120 days from planting date to study the following characteristics:-

1- Fresh weight/plant. ( $\mathrm{g}$ )

2- Dry weight/plant. ( $\mathrm{g}$ )

3- Leaf area $\left(\mathrm{cm}^{2}\right) /$ plant.

4- Bulbing ratio $=\frac{\text { Neck diameter }(\mathrm{cm})}{\text { Bulb diameter }(\mathrm{cm})}$ Mann (1952) after 120 and 160 days from planting.

5- Bulb diameter $(\mathrm{cm})$ after 160 days from planting.

B. Yield and its components

1- Total yield ton/ feddan before curing treatment.

2- Average bulb weight (g).

C. Chemical composition

1. Total chlorophyll (was estimated by spectrophotometrically by using the method of Macking (1941).

2.Nitrogen, phosphorus and potassium percentage in the dry matter of cured cloves were determined according to methods described by AOAC (1990) for nitrogen, phosphorus and potassium by Ranganna (1979).

\section{Storability}

After curing random samples (each $10 \mathrm{~kg}$ ) were taken from every treatment and stored at the normal room conditions.

The samples were weight after one, three and six months later and percentage of loss weight were calculated.

The obtained data were subjected to statistical analysis using technique of the randomized complete block design according to Snedecor and Cochran (1982) using MSTAT-C, computer. The treatment means were compared using Duncan's Multiple Range Test (Duncan, 1955).

\section{RESULTS AND DISCUSSION}

\section{A- Vegetative growth characters}

Data on vegetative growth characters i.e. Fresh weight/plant, dry weight/plant, Leaf area $\left(\mathrm{cm}^{2}\right) /$ plant and bulbing ratio were present in Table 1. The highest values (Fresh weight/plant, dry weight/plant, Leaf area $\left(\mathrm{cm}^{2}\right) /$ plant)were recorded with $30 \mathrm{~m}^{3} / \mathrm{fed}$ cattle manure $+50 \mathrm{~kg} \mathrm{P}_{2} \mathrm{O}_{5} / \mathrm{fed}+$ with phosphorien $(3 \mathrm{~kg} / \mathrm{fed})+60 \mathrm{~kg} \mathrm{~K} \mathrm{~K}_{2} \mathrm{O} / \mathrm{fed}+1 \% \mathrm{~K}_{2} \mathrm{O} / \mathrm{fed}$ foliar fertilization. 
El - Gazar, T. M. et al.

1 
This significantly overcome other treatments but this treatment had the lowest value of bulbing ratio in the first season.

The application of cattle manure and phosphorien on vegetative growth often due to improving the structure of soil and increase total count of botany as well as, improving soil biological and chemical properties. Moreover, the supplied organic manure amended the microorganisms with necessary nutrient elements and increased the microbial respiration and $\mathrm{CO}_{2}$ out put (Cook 1972 and 1982).

On the other hand, the favorable effect of potassium fertilizer on the plant growth may be due to that potassium element is very important in the overall metabolism of plant (Mengel and Kirkby, 1982). Moreover, foliar fertilization of potassium is more economical than root application due to the higher degree of applied nutrient utilization and the continuous increases in the costs of using chemical fertilizers (Franke, 1986). Similar results were obtained by, El-Sheekh (1997), Al-Kaff et al. (2002), Muthuramalingam et al. (2002), Prabu et al. (2003), Lee Tong Tae et al. (2003), El-Morsy et al. (2004), El-Shaikh (2005), Jha et al. (2006), Nikardi (2009), Shaheen et al. (2009) and Yassen and Khalid (2009).

\section{B- Yield and its components}

Data presented in Table 2 show that application of $30 \mathrm{~m}^{3} / \mathrm{fed}$ cattle manure $+50 \mathrm{~kg} \mathrm{P} \mathrm{O}_{5} / \mathrm{fed}+$ with phosphorien $(3 \mathrm{~kg} / \mathrm{fed})+60 \mathrm{~kg} / \mathrm{fed} \mathrm{K}_{2} \mathrm{O}+1 \%$ $\mathrm{K}_{2} \mathrm{O} / \mathrm{fed}$ foliar fertilization resulted in the highest values (diameter of bulb at 160 days from planting, weight of bulb and bulb yield/fed). However, bulbing ratio at 160 days after planting was significantly affected by $30 \mathrm{~m}^{3} / \mathrm{fed}$ cattle manure $/ \mathrm{fed}+25 \mathrm{~kg} \mathrm{P} \mathrm{O}_{5} / \mathrm{fed}+$ without phosphorien $+72 \mathrm{~kg} / \mathrm{fed} \mathrm{K}_{2} \mathrm{O}$ during both seasons. The results are similar to those reported by Al-Kaffe et al. (2002), Muthuramalingam et al. (2002), Prabu et al. (2003), El-Mansi et al. (2004), El-Morsy et al. (2004), Nikardi (2009), Shaheen et al. (2009) and Yassen and Khalid (2009).

The enhancing effect of such treatments on yield and its components are mainly attributed to the ameliorative effect on vegetative growth Table 1.

\section{C- Chemical composition}

Results recorded in Table 3 reveal that Nitrogen, phosphorus and potassium in garlic cloves and chlorophyll contents in leaves had the highest values at the treatment of $30 \mathrm{~m}^{3} / \mathrm{fed}$ cattle manure $+50 \mathrm{~kg} \mathrm{P} \mathrm{P}_{2} / \mathrm{fed}+$ with phosphorien $+60 \mathrm{~kg} \mathrm{~K} 2 \mathrm{O} / \mathrm{fed}+1 \% \mathrm{~K}_{2} \mathrm{O} / \mathrm{fed}$ foliar fertilization during both seasons of study. Such increments are connected with the increasing in vegetative growth parameter also it may be attributed to the highest content and more as well easily decomposition of cattle manure, phosphorien and availability of such macro elements N, P, K and total chlorophyll for absorption by plant roots compared with treatments. Obtained results as in agreement with those reported by Muthuramalingam et al. (2002), Prabu et al. (2003), El-Shaikh (2005) and Jha et al. (2006). 
El - Gazar, T. M. et al.

2 
J. Plant Production, Mansoura University, Vol. 1 (7), July, 2010

3

955 


\section{El - Gazar, T. M. et al.}

In addition, the increment up take of $\mathrm{N}, \mathrm{P}$ and $\mathrm{K}$ by different plants parts may be due to higher availability of the nutrients with increase in the fertilizer application NPK which ultimately resulted in better root growth and increased physiological activity of roots to absorb the nutrients and thereby nutrient up take was found closely linked with productivity (Veeranna et al. 1997). Similar results were obtained by Ciecko et al. (2000), El-Morsy et al. (2004), Nikardi (2009), Shaheen et al. (2009) and Yassen and Khalid (2009).

\section{D- Storability}

Data presented in Table 4 showed that the response of weight loss percentage of bulbs to the different treatments. The data indicated that $30 \mathrm{~m}^{3}$ /fed cattle manure $+75 \mathrm{~kg} \mathrm{P} \mathrm{O}_{5} / \mathrm{fed}+$ with phosphorien $+60 \mathrm{~kg} \mathrm{~K} 2 \mathrm{O}+1 \%$ $\mathrm{K}_{2} \mathrm{O} / \mathrm{fed}$ foliar fertilization gave the lowest weight loss percentage during storage period at the first season. But, the application of $30 \mathrm{~m}^{3} / \mathrm{fed}$ cattle manure $+50 \mathrm{~kg} \mathrm{P} \mathrm{P}_{5} / \mathrm{fed}+$ with phosphorien $+60 \mathrm{~kg} \mathrm{~K} 2 \mathrm{O} / \mathrm{fed}+1 \% \mathrm{~K}_{2} \mathrm{O} / \mathrm{fed}$ foliar fertilization gave the lowest values at the second season.

Table 4: Weight loss percentage after one, three and six months of garlic as affected by combination among cattle manure, phosphorus levels, phosphorien and potassium fertilizer during 2003/2004 and 2004/2005 seasons.

\begin{tabular}{|c|c|c|c|c|c|c|}
\hline \multirow[b]{2}{*}{ Treatments } & \multicolumn{2}{|c|}{$\begin{array}{c}\text { Weight loss } \\
\text { percentage } \\
\text { after one month }\end{array}$} & \multicolumn{2}{|c|}{$\begin{array}{l}\text { Weight loss } \\
\text { percentage after } \\
\text { three months }\end{array}$} & \multicolumn{2}{|c|}{\begin{tabular}{|c|} 
Weight loss \\
percentage after six \\
months
\end{tabular}} \\
\hline & $\begin{array}{c}2003 / \\
2004\end{array}$ & $\begin{array}{c}2004 / \\
2005\end{array}$ & $\begin{array}{c}2003 / \\
2004\end{array}$ & $\begin{array}{c}2004 / \\
2005\end{array}$ & $\begin{array}{c}2003 / \\
2004\end{array}$ & $\begin{array}{c}2004 / \\
2005\end{array}$ \\
\hline $20 \mathrm{~m}^{3} \mathrm{CM}+\mathrm{P}_{1}+\mathrm{Wt} . \mathrm{Ph}+\mathrm{Ks}$ & $2.75 \mathrm{a}$ & $2.75 \mathrm{j}$ & $7.50 \mathrm{f}$ & $8.00 \mathrm{~h}$ & $14.50 \mathrm{n}$ & $14.50 \quad$ I \\
\hline $20 \mathrm{~m}^{3} \mathrm{CM}+\mathrm{P}_{1}+\mathrm{Wt} . \mathrm{Ph}+\mathrm{K}(\mathrm{s}+\mathrm{f})$ & $1.04 \mathrm{f}$ & $2.65 \mathrm{k}$ & 6.19 & 7.70 & $15.63 \mathrm{i}$ & $7.00 \mathrm{~h}$ \\
\hline $20 \mathrm{~m}^{3} \mathrm{CM}+\mathrm{P}_{1}+\mathrm{W} \cdot \mathrm{Ph}+\mathrm{Ks}$ & $2.00 \mathrm{~b}$ & $5.20 \mathrm{~d}$ & $8.00 \mathrm{e}$ & $10.20 \mathrm{~d}$ & $16.62 \mathrm{f}$ & $0 \quad b$ \\
\hline $20 \mathrm{~m}^{3} \mathrm{CM}+\mathrm{P}_{1}+\mathrm{W} . \mathrm{Ph}+\mathrm{K}(\mathrm{s}+\mathrm{f})$ & $1.50 \mathrm{~d}$ & $4.60 \mathrm{e}$ & 6.25 & $10.67 \mathrm{C}$ & $13.50 \mathrm{q}$ & $8.50 \mathrm{~g}$ \\
\hline $20 \mathrm{~m}^{3} \mathrm{CM}+\mathrm{P}_{2}+\mathrm{Wt} . \mathrm{Ph}+\mathrm{Ks}$ & $1.00 \mathrm{f}$ & 0.60 & $5.75 \quad 1$ & 6.00 & $15.00 \quad$ I & $0 \mathrm{~m}$ \\
\hline $20 \mathrm{~m}^{3} \mathrm{CM}+\mathrm{P}_{2}+\mathrm{Wt} . \mathrm{Ph}+\mathrm{K}(\mathrm{s}+\mathrm{f})$ & $1.00 \mathrm{f}$ & 1.600 & $6.00 \mathrm{k}$ & 6.55 no & $14.00 \quad 0$ & $14.50 \quad \mathrm{I}$ \\
\hline $20 \mathrm{~m}^{3} \mathrm{CM}+\mathrm{P}_{2}+\mathrm{W} \cdot \mathrm{Ph}+\mathrm{Ks}$ & $2.00 \mathrm{~b}$ & $2.15 \mathrm{~m}$ & $8.50 \mathrm{c}$ & $8.60 \mathrm{~g}$ & $19.25 \mathrm{C}$ & $19.34 \mathrm{f}$ \\
\hline $20 \mathrm{~m}^{3} \mathrm{CM}+\mathrm{P}_{2}+\mathrm{W} . \mathrm{Ph}+\mathrm{K}(\mathrm{s}+\mathrm{f})$ & $2.75 \mathrm{a}$ & $5.32 \mathrm{bc}$ & $9.75 \quad \mathrm{a}$ & $12.00 \mathrm{~b}$ & $20.25 \quad \mathrm{a}$ & 24.00 \\
\hline $20 \mathrm{~m}^{3} \mathrm{CM}+\mathrm{P}_{3}+\mathrm{Wt} . \mathrm{Ph}+\mathrm{Ks}$ & $0.78 \mathrm{~g}$ & $2.02 n$ & $5.16 \mathrm{n}$ & $6.60 \mathrm{mn}$ & $13.61 p$ & $15.28 \mathrm{j}$ \\
\hline $20 \mathrm{~m}^{3} \mathrm{CM}+\mathrm{P}_{3}+\mathrm{Wt} \cdot \mathrm{Ph}+\mathrm{K}(\mathrm{s}+\mathrm{f})$ & $1.31 \mathrm{e}$ & $3.35 \mathrm{~h}$ & $7.43 \mathrm{f}$ & $6.20 \quad \mathrm{q}$ & $16.32 \mathrm{~g}$ & $14.25 \mathrm{~m}$ \\
\hline $20 \mathrm{~m}^{3} \mathrm{CM}+\mathrm{P}_{3}+\mathrm{W} \cdot \mathrm{Ph}+\mathrm{Ks}$ & $1.50 \mathrm{~d}$ & $4.15 \mathrm{~g}$ & $6.50 \mathrm{i}$ & $12.80 \mathrm{a}$ & $15.50 \mathrm{j}$ & $21.20 \mathrm{c}$ \\
\hline $20 \mathrm{~m}^{3} \mathrm{CM}+\mathrm{P}_{3}+\mathrm{W} \cdot \mathrm{Ph}+\mathrm{K}(\mathrm{s}+\mathrm{f})$ & $0.50 \mathrm{~h}$ & $1.10 \mathrm{r}$ & 5.000 & $6.55 \mathrm{no}$ & $13.50 \mathrm{q}$ & $14.00 \mathrm{n}$ \\
\hline $30 \mathrm{~m}^{3} \mathrm{CM}+\mathrm{P}_{1}+\mathrm{Wt} \cdot \mathrm{Ph}+\mathrm{Ks}$ & $1.75 \mathrm{c}$ & $2.05 \mathrm{n}$ & $9.25 \mathrm{~b}$ & 6.00 & $19.75 \mathrm{~B}$ & $20.00 \mathrm{e}$ \\
\hline $30 \mathrm{~m}^{3} \mathrm{CM}+\mathrm{P}_{1}+\mathrm{Wt} \cdot \mathrm{Ph}+\mathrm{K}(\mathrm{s}+\mathrm{f})$ & $0.78 \mathrm{~g}$ & 2.351 & $5.47 \mathrm{~m}$ & 7.00 & $15.75 \mathrm{~h}$ & $17.08 \mathrm{~h}$ \\
\hline $30 \mathrm{~m}^{3} \mathrm{CM}+\mathrm{P}_{1}+\mathrm{W} \cdot \mathrm{Ph}+\mathrm{Ks}$ & $0.77 \mathrm{~g}$ & $1.40 \mathrm{q}$ & $5.09 \mathrm{no}$ & $6.68 \mathrm{Im}$ & $15.08 \quad$ I & $15.60 \mathrm{i}$ \\
\hline $30 \mathrm{~m}^{3} \mathrm{CM}+\mathrm{P}_{1}+\mathrm{W} . \mathrm{Ph}+\mathrm{K}(\mathrm{s}+\mathrm{f})$ & $1.50 \mathrm{~d}$ & $4.30 \mathrm{f}$ & $7.25 \mathrm{~g}$ & 9.00 & $18.25 \mathrm{~d}$ & $20.61 \mathrm{~d}$ \\
\hline $30 \mathrm{~m}^{3} \mathrm{CM}+\mathrm{P}_{2}+\mathrm{Wt} . \mathrm{Ph}+\mathrm{Ks}$ & $1.25 \mathrm{e}$ & $5.25 \mathrm{~cd}$ & $8.25 \mathrm{~d}$ & 6.40 & $18.00 \mathrm{e}$ & $13.40 \quad 0$ \\
\hline $30 \mathrm{~m}^{3} \mathrm{CM}+\mathrm{P}_{2}+\mathrm{Wt} . \mathrm{Ph}+\mathrm{K}(\mathrm{s}+\mathrm{f})$ & $1.25 \mathrm{e}$ & $1.00 \mathrm{~s}$ & $5.50 \mathrm{~m}$ & 6.00 & $14.75 \mathrm{~m}$ & $12.20 \mathrm{p}$ \\
\hline $30 \mathrm{~m}^{3} \mathrm{CM}+\mathrm{P}_{2}+\mathrm{W} \cdot \mathrm{Ph}+\mathrm{Ks}$ & $1.50 \mathrm{~d}$ & $1.50 p$ & $7.25 \mathrm{~g}$ & 6.70 & $14.50 \mathrm{n}$ & $14.00 \mathrm{n}$ \\
\hline $30 \mathrm{~m}^{3} \mathrm{CM}+\mathrm{P}_{2}+\mathrm{W} . \mathrm{Ph}+\mathrm{K}(\mathrm{s}+\mathrm{f})$ & $1.50 \mathrm{~d}$ & $0.50 \mathrm{u}$ & $6.75 \mathrm{~h}$ & 5.00 & $14.73 \mathrm{~m}$ & 10.50 \\
\hline $30 \mathrm{~m}^{3} \mathrm{CM}+\mathrm{P}_{3}+\mathrm{Wt} . \mathrm{Ph}+\mathrm{Ks}$ & $1.31 \mathrm{e}$ & $1.00 \mathrm{~s}$ & $5.76 \quad \mathrm{I}$ & 6.10 & $15.20 \mathrm{k}$ & $11.50 \mathrm{q}$ \\
\hline $30 \mathrm{~m}^{3} \mathrm{CM}+\mathrm{P}_{3}+\mathrm{Wt} . \mathrm{Ph}+\mathrm{K}(\mathrm{s}+\mathrm{f})$ & $1.50 \mathrm{~d}$ & $5.50 \quad \mathrm{a}$ & $6.25 \mathrm{~J}$ & $10.00 \mathrm{e}$ & $14.79 \mathrm{~m}$ & $18.50 \mathrm{~g}$ \\
\hline $30 \mathrm{~m}^{3} \mathrm{CM}+\mathrm{P}_{3}+\mathrm{W} . \mathrm{Ph}+\mathrm{Ks}$ & $1.47 \mathrm{~d}$ & $5.40 \mathrm{~b}$ & $5.75 \quad 1$ & 6.50 & $13.22 \mathrm{r}$ & $17.06 \mathrm{~h}$ \\
\hline $30 \mathrm{~m}^{3} \mathrm{CM}+\mathrm{P}_{3}+\mathrm{W} \cdot \mathrm{Ph}+\mathrm{K}(\mathrm{s}+\mathrm{f})$ & $0.78 \mathrm{~g}$ & $3.15 \mathrm{i}$ & $4.53 \mathrm{p}$ & 7.40 & $12.67 \mathrm{~s}$ & $14.75 \mathrm{k}$ \\
\hline 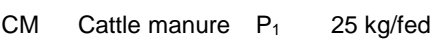 & & & & & & \\
\hline hos & & & & 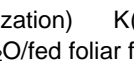 & 6 & \\
\hline
\end{tabular}


These results may be due to increase dry weight in plant Table 1 and $\mathrm{K}$ element in Table 2 the reduction in percentage of weight loss during storage may be due to low moist content in bulb reflected as observed in the dry matter percentage. Also, phosphorus is required for the production of high energy phosphate molecules, produced in both photosynthesis and respiration processes therefore higher content of ATP reduced the degradation of clove content for respiration and hence less lose from bulb during storage period. The presence of the micro-organisms found cattle manure and phosphorien may secrete antioxidant and suppressed pests and diseases which could be the major reason for reducing weight loss during storage (Cook 1982; Mengel and Kirkby, 1982 and Gardener et al., 1985).

\section{REFERENCES}

Abd El-Aal, M. S. (1990). Effect of nitrogen, phosphorus and potassium fertilization on the productivity of fodder bett. Egypt. J. Agron., 15(1-2): 159-170.

Abd El-Rehim, G. H. (2000). Effect of phosphorus fertilization on yield and quality of onion bulbs under upper Egypt conditions. Assiut J. Agric. Sci., 31(3): 115-121, Egypt.

Abou El-Magd, M. M.; H. M. Mohamed and M. S. El-Bassyouni (2003). Comparing the effect of some organic manure and mineral fertilizers on growth, yield and quality of onion (Allium cepa L). Egypt. J. Appl. Sci.,, 18 (12B): 675-692.

Al-kaff, H. A.; O. S. Saeed and A. Z. Salim (2002). Effect of biofertilizers, inorganic, organic and foliar application of power 4 on the productivity of onion. Unvi. of Aden J. Of Natural and Applied Sci., 6:1, 1-14; 17. (cf. CAB Abst.).

Al-Karaki G. N. (2002). Field response of garlic inoculated with arbuscular mycorrhizal fungi to phosphorus fertilization. J. of Plant Nutrition, 25(4): 747-756.

Alok, Singh; S. P. Singh and B. P. Singh (2002). Effect of VAM and inorganic fertilizers on yield and NP content and up take in onion (Allium cepa L.). Vegetable Sci., 29(2): 161-163.

AOAC (1990). Association of official analytical chemists. Official Methods of Analysis $15^{\text {th }}$ Ed. Washington Ds USA.

Ciecko, Z.; M. Wyszkowski.; A. Zonowski and J. Zabielska (2000). Influence of NPK, Mg and $\mathrm{K}$ application on chlorophyll content in potato leaves (cf. CAB Abstr.).

Cook, G. W. (1972). Fertilizing for maximum yield. Richard clay Itd. Hungary Suffok Great Britain, 457.

Cook, G. W. (1982). Fertilizing maximum yield. part two. sources of plant Nutrients for improving soil fertility .6. organic Manure and Fertilizers, 94-95.

Duncan, D. B.(1955). Multiple range and multiple F test. Biometrics, 11: 1-42. 
El-Dahtory, T. H.; M. Abd El-Nasser.; A. R. Abd Allah and M. A. El-Mohandes (1989). Studies on phosphate solubilizing bacteria under different soil amendments. Minia J. Agric. Res. Dev., 11(2): 935-950, Egypt.

El-Kalla, S. E.; A. K. Mostafa, A. A. Leilah and Rokia A. Awad (1997). Mineral and biophosphatic fertilization faba bean and onion. Egypt. J. Agric. Res., 77(1): 253-271.

El-Kalla, S. E.; A. K. Mostafa.; A. A. Leilah and Rokia A. Awwad (1999). Mineral and bio-phosphatic fertilization for intercropped faba bean and onion. Agric. Res., J. 77(1): 253-271, Egypt.

El-Mansi, A. A.; A. Bardisi.; H. M. E. Arisha and E. M. Nour (1999). Studies on some factors affecting growth and yield of pea under sandy soil conditions using drip irrigation system. 2. Effect of farmyard manure and irrigation water quantity. Zagazig J. Agric. Res., 26(5): 1409-1428.

El-Mansi, A. A.; A. Bardisi,; A. N. Fayad and E. E. Abou El-Khair (2004). Effect of water quantity and farmyard manure on garlic under sandy soil conditions -II- Yield and its components water use efficiency and bulb quality. Zagazig J. Agric. Res., 31(4A): 1385-1408.

El-Morsy, A. H. A.; Z. S. El-Shal and Sawsan H. Sarg (2004). Effect of potassium application methods and some micronutrients on growth, yield and storability of garlic. J. Agric. Sci. Mansoura Univ., 29(4): 2013-2023.

El-Shaikh, A. A. (2005). Growth and yield of onion as affected by biofertilization, application of nitrogen and phosphorus fertilizers under south valley conditions. Assiut J. Agric. Sci., 36(1): 37-50.

El-Sheekh, H. M. (1997). Effect of bio and mineral phosphate fertilizers on growth, yield, quality and storability of onion. Egypt. J. Appl. Sci., 12(123): 213-231.

Forster, I. and K. Freter (1988). Contributions to the mobilization of phosphorus by soil microorganisms $4^{\text {th }}$ communication investigation of the efficiency of $\mathrm{P}$ mobilizing microorganisms in vitro and in the rhizophere of some higher plants. Agrobiology, 5: 9-14 (cf. soils and fertilizers, 15-7903).

Franke, W. (1986). The basis of foliar absorption of fertilizers with special regard to the mechanisms. "Foliar fertilization" Ed. By Alexander. Schering Agrochemical Division, special fertilizer group, Berlin (FRG), PP 17-25.

Gardener, F. P.; R. B. Peraco and R. L. Mitchell (1985). Physiological of crop plants. First Ed. lowa State Univ. Press, Ames, 277p.

Jakse, M. and R. Mihelic (2001). Comparison of fertilization with organic or mineral fertilizers in a three year vegetable crop rotation. (cf. $C A B$ Abstr.).

Jha, A. K.; Netra-Pal, A. K. Saxena, Dhyan-Singh and G. K. Jha (2006). Coinoculation effect of VAM and PGPR on growth and yield of onion. Indian J. Hort., 63(1): 44-47.

Lee Jong Tae; Ha In Jong.; Lee Chan Jung.; Moon Jin Seong and Cho Yong Cho (2003). Effect of $\mathrm{N}, \mathrm{P}_{2} \mathrm{O}_{5}$ and $\mathrm{K}_{2} \mathrm{O}$ application rates and top dressing time on growth and yield of onion (Allium cepa L.) under spring culture in low land. (cf. CAB Abstr.). 
Macking, G. (1941). Absorption of light by cholorphyll solution. J. Biol. Chem., 140: 315-322.

Mahmoud, S. A. and A. M. Abd El-Hafez (1982). The role of phosphate mobilizing bacteria in plant nutrition. The $1^{\text {st }}$ OAU/STRC Inter Africanconf on "Biofertilizers", Cairo 22-26 March, 1982, Egypt.

Mann, L. K. (1952). Anatomy of the garlic bulb and factors affecting bulb development. Hilgardia, 21: 195-228.

Mengel, K. and E. A. Kirkby (1982). Textbook of principles of plant Nutrition. $3^{\text {rd }}$ Ed. PP 55. International Potash Institute, Bern, Switzerland.

Muthuramalingam, S.; S. S. Kumaran, I. Muthurel and V. A. Sathiyamurthy (2002). Influence of plant densities and applied nutrients on up take of NPK in seed propagated aggregatum onion (Allium cepa L.) var. aggregatum Gnanamedu local type. (cf. Abstracts 2002).

Nikardi G. (2009). Response of potato to potassium fertilizer sources and application methods in Andisols of west java. Indonesian J. Agric. Sci., 10(2): 65-72.

Patil, P. V.; P. B. Chalwade, A. S. Solanke and V. K. Kulkarni (2005). Effect of Fly ash and FYM on nutrient up take and yield of onion. (cf. CAB Abstr. 162/229.

Prabu, T.; P. R. Narwadkar, A. K. Sajindranath and R. S. Jadhar (2003). Correlation studies of okra. J. of Soil and Crops 13:1, 170-171. (cf. CAB Abst.).

Ranganna, S. (1979). Manual analysis of fruit and vegetable products. Tata Mc Grow Hill Publishing Company Limited New Delhi, pp 634.

Russell, E. J. (1950). Soil conditions and plant growth. Longmans, Green and Co. London, : 39.39 .

Said, Th. A. (1997). Effect of some fertilization treatments on yield and chemical composition of fodder beet at Ras Sudr region. M. Sc. Thesis Fac. Of Agric., Ain Shams Univ., Egypt.

Santhi, R.; R. Natesan and G. Selvakama (2005). Effect of soil fertility and integ rated plant nutrition system on yield, response and nutrient up take by aggregatum onion. Indian J. of Agric. Res., 39(3): 312-316.

Sari, N.; I. Ortas and H. Yetisir (2002). Effect of mycorrhizae inoculation on plant growth, yield and phosphorus up take in garlic under field conditions. Communications in Soil Sci. and Plant Analysis 33(13/14): 2189-2201.

Setty, B. S.; G. S. Sulikeni and N. C. Hulamani (1989). Effect of N, P and K on growth and yield of garlic (Allium sativum L.). India Karnataka J. of Agric. Sci., 2(3): 160-164 ( Cf. Hort. Abst.).

Shaheen, A. M.; Faten S. Abd El-Aal, A. A. Ahmed and A. Rezk Fatma. (2009). The influence of application methods of potassium fertilization on growth, pods yield and its quality of pea plants. J. Agric. Sci. Mansoura Univ., 34(12):11271-11283.

Snedecor, G. H. and W. G. Cochran (1982). Statistical Methods. lowa state Univ. press USA. $6^{\text {th }}$ Ed pp 34-93.

Turk, M. A. and A. M. Tawaha (2001). Influence of rate and method of phosphorus placement to garlic (Allium Sativum L.) in Mediterranean environment. Journal of Applied Horticulture LucKnow, 3(2): 115-116. 


\section{EI - Gazar, T. M. et al.}

Veeranna, H. K.; Abdul Khalah and Muldalagiriyoppa (1997). Bulking rates, grade wise and total yield of tubers as influenced by spacing and fertilizer levels in potato crop raised from TPS seedlings. Mysore J. Agric. Sci., 31: 60-65.

Yassen, A. A. and Kh. A. Khalid (2009). Influence of organic fertilizers on yield, essential oil and mineral content of onion. International Agro Physics, 23: 183-188.

$$
\begin{aligned}
& \text { تأثثر بعض الأسمدة العضوية و الاسمدة الكيماوية و الحيوية على محصول الثوم: }
\end{aligned}
$$

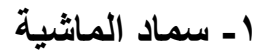

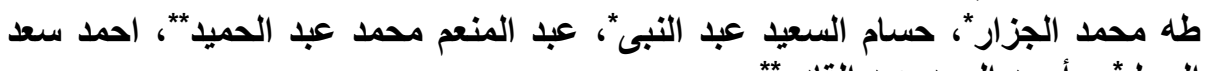

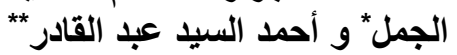

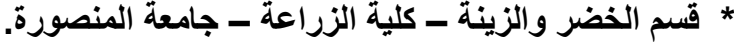

$$
\begin{aligned}
& \text { ** قسم بحوث الخضر - معهر بحوث البساتين - مركز البحوث الزئة الزراعية }
\end{aligned}
$$

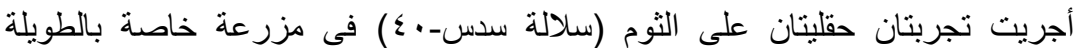

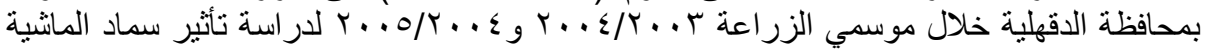

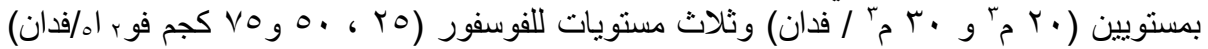

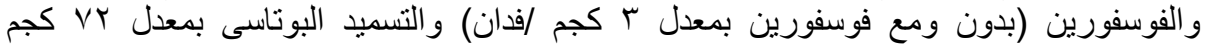

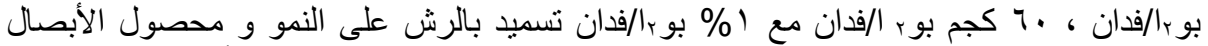

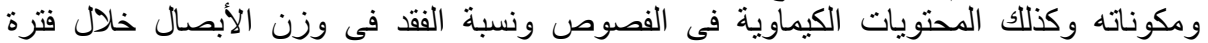

$$
\text { التخزين. }
$$

ويمكن تلخيص النتائج المتحصل عليها فيما يلى:-

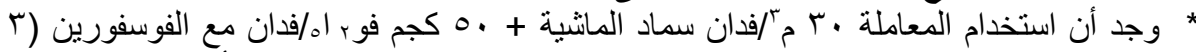

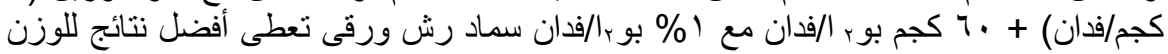

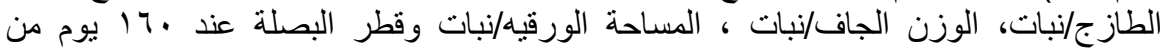

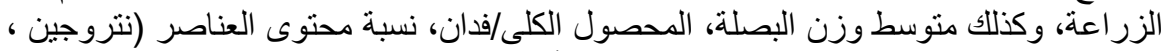

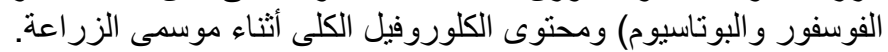

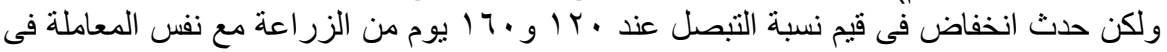

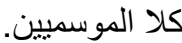
* مع نفس المعاملة حدث انخفاض فى نسبة الفقد الكلية فى وزن الأبصال المخزنة فى الموسم الثنانى

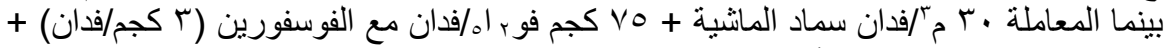

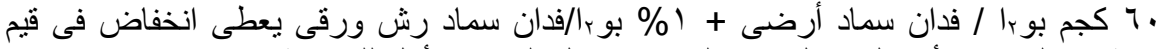

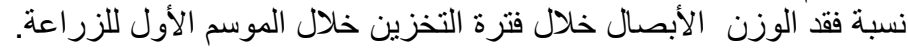

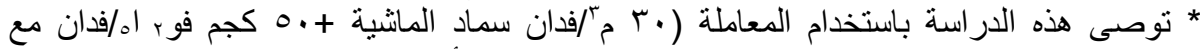

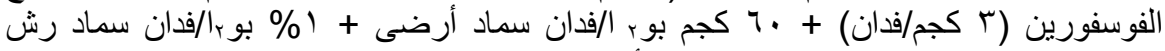
ورقى) لرفع إنتاجية الثوم وتحسين جودة الأبصال وقابليتها للتخزين.

$$
\text { كلية الزراعة - جامعة - جامعة المنصورة }
$$

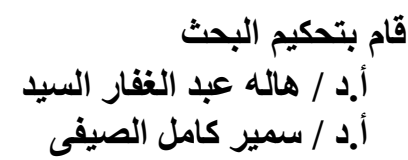

قام بتحكيم البحث 
Table 1: Fresh and dry weights/plant, leaf area /plant and bulbing ratio of garlic as affected by combination among cattle manure, phosphorus levels, phosphorien and potassium fertilizer at $\mathbf{1 2 0}$ days after planting during 2003/2004 and 2004/2005 seasons.

\begin{tabular}{|c|c|c|c|c|c|c|c|c|c|c|c|c|c|c|c|}
\hline \multirow{2}{*}{$\begin{array}{c}\text { Characters } \\
\text { Treatments } \\
\end{array}$} & \multicolumn{4}{|c|}{ Fresh weight/plant (g) } & \multicolumn{4}{|c|}{ Dry weight/plant (g) } & \multicolumn{3}{|c|}{ Leaf area /plant $\left(\mathrm{cm}^{2}\right)$} & \multicolumn{4}{|c|}{ Bulbing ratio } \\
\hline & \multicolumn{2}{|c|}{$2003 / 2004$} & \multicolumn{2}{|c|}{$2004 / 2005$} & \multicolumn{2}{|c|}{$2003 / 2004$} & \multicolumn{2}{|c|}{$2004 / 2005$} & \multicolumn{2}{|c|}{ 2003/2004 } & $2004 / 2005$ & \multicolumn{2}{|c|}{$2003 / 2004$} & \multicolumn{2}{|c|}{$2004 / 2005$} \\
\hline & 67.92 & bcdefg & 83.11 & $\mathrm{De}$ & 5.43 & $\mathrm{~d}$ & 8.00 & $\mathrm{e}$ & 150.40 & $\mathrm{~h}$ & 195.52 & 0.432 & $\mathrm{a}$ & 0.388 & $\mathrm{a}$ \\
\hline $20 \mathrm{~m}^{3} \mathrm{CM}+\mathrm{P}_{1}+\mathrm{Wt} \cdot \mathrm{Ph}+\mathrm{K}(\mathrm{s}+\mathrm{f})$ & 68.29 & bcdefg & 84.00 & Cde & 5.50 & $\mathrm{~d}$ & 8.76 & abcde & 150.91 & $\mathrm{~h}$ & 199.18 & 0.428 & $\mathrm{a}$ & 0.391 & $\mathrm{a}$ \\
\hline $20 \mathrm{~m}^{3} \mathrm{CM}+\mathrm{P}_{1}+\mathrm{W} \cdot \mathrm{Ph}+\mathrm{Ks}$ & 70.63 & abcdef & 87.00 & Bcd & 6.15 & bcd & 8.45 & cde & 151.12 & $\mathrm{~h}$ & 202.18 & 0.408 & $a b$ & 0.384 & $\mathrm{a}$ \\
\hline $20 \mathrm{~m}^{3} \mathrm{CM}+\mathrm{P}_{1}+\mathrm{W} \cdot \mathrm{Ph}+\mathrm{K}(\mathrm{s}+\mathrm{f})$ & 69.06 & bcdefg & 87.00 & Bcd & 6.51 & bcd & 8.70 & abcde & 152.50 & gh & 219.80 bcde & & $\mathrm{ab}$ & 321 & $\mathrm{a}$ \\
\hline $20 \mathrm{~m}^{3} \mathrm{CM}+\mathrm{P}_{2}+\mathrm{Wt} . P \mathrm{Ph}+\mathrm{Ks}$ & 71.33 & abcdef & 83.00 & $\mathrm{De}$ & 7.07 & abcd & 8.47 & bcde & 155.31 & fgh & 211.80 efgh & 0.405 & $a b$ & 0.323 & $\mathrm{a}$ \\
\hline $20 \mathrm{~m}^{3} \mathrm{CM}+\mathrm{P}_{2}+\mathrm{Wt} \cdot P \mathrm{Ph}+\mathrm{K}(\mathrm{s}+\mathrm{f})$ & 72.46 & abcde & 86.00 & Bcde & 6.38 & $\mathrm{bcd}$ & 8.81 & abcde & 156.52 & fgh & $221.26 \mathrm{abcd}$ & 0.393 & $a b$ & 0.370 & $\mathrm{a}$ \\
\hline $20 \mathrm{~m}^{3} \mathrm{CM}+\mathrm{P}_{2}+\mathrm{W} \cdot \mathrm{Ph}+\mathrm{Ks}$ & 64.40 & $\mathrm{fg}$ & 78.33 & $\mathrm{E}$ & 6.46 & bcd & 8.04 & $\mathrm{e}$ & 157.10 & efgh & 203.16 ghij & 0.335 & $\mathrm{ab}$ & 0.380 & $\mathrm{a}$ \\
\hline $20 \mathrm{~m}^{3} \mathrm{CM}+\mathrm{P}_{2}+\mathrm{W} \cdot \mathrm{Ph}+\mathrm{K}(\mathrm{s}+\mathrm{f})$ & 68.73 & bcdefg & 91.66 & $\mathrm{abc}$ & 6.53 & $\mathrm{bcd}$ & 8.12 & de & 154.70 & fgh & 205.04 fghij & 0.379 & $a b$ & 0.362 & $\mathrm{a}$ \\
\hline $20 \mathrm{~m}^{3} \mathrm{CM}+\mathrm{P}_{3}+\mathrm{Wt} \cdot \mathrm{Ph}+\mathrm{Ks}$ & 63.33 & $\mathrm{fg}$ & 85.33 & bcde & 6.78 & $\mathrm{bcd}$ & 8.54 & bcde & 154.52 & fgh & 218.56 bcde & 0.375 & $a b$ & 0.356 & $\mathrm{a}$ \\
\hline $20 \mathrm{~m}^{3} \mathrm{CM}+\mathrm{P}_{3}+\mathrm{Wt} \cdot \mathrm{Ph}+\mathrm{K}(\mathrm{s}+\mathrm{f})$ & 73.63 & $\mathrm{abc}$ & 88.00 & abcd & 7.49 & $a b c$ & 9.42 & $a b c$ & 164.32 & defgh & 219.80 bcde & 0.355 & $a b$ & 0.337 & $\mathrm{a}$ \\
\hline $20 \mathrm{~m}^{3} \mathrm{CM}+\mathrm{P}_{3}+\mathrm{W} \cdot \mathrm{Ph}+\mathrm{Ks}$ & 63.90 & $\mathrm{fg}$ & 88.33 & abcd & 6.46 & $\mathrm{bcd}$ & 8.46 & cde & 175.41 & $\mathrm{abc}$ & 209.54 efghi & 0.332 & $a b$ & 0.361 & $\mathrm{a}$ \\
\hline $20 \mathrm{~m}^{3} \mathrm{CM}+\mathrm{P}_{3}+\mathrm{W} \cdot \mathrm{Ph}+\mathrm{K}(\mathrm{s}+\mathrm{f})$ & 73.12 & abcd & 86.00 & bcde & 6.55 & $\mathrm{bcd}$ & 9.25 & abcde & 173.91 & abcde & 214.05 cdefg & 0.318 & $\mathrm{~b}$ & 0.345 & $\mathrm{a}$ \\
\hline $30 \mathrm{~m}^{3} \mathrm{CM}+\mathrm{P}_{1}+\mathrm{Wt} \cdot \mathrm{Ph}+\mathrm{Ks}$ & 62.53 & $\mathrm{~g}$ & 93.33 & $a b$ & 5.91 & $\mathrm{~cd}$ & 8.92 & abcde & 156.50 & efgh & 203.31 ghij & 0.328 & $a b$ & 0.353 & $\mathrm{a}$ \\
\hline $30 \mathrm{~m}^{3} \mathrm{CM}+\mathrm{P}_{1}+\mathrm{Wt} \cdot \mathrm{Ph}+\mathrm{K}(\mathrm{s}+\mathrm{f})$ & 66.33 & cdefg & 85.66 & bcde & 6.21 & bcd & 8.68 & abcde & 157.61 & efgh & 206.84 fghi & 0.341 & $\mathrm{ab}$ & 0.355 & $\mathrm{a}$ \\
\hline $30 \mathrm{~m}^{3} \mathrm{CM}+\mathrm{P}_{1}+\mathrm{W} \cdot \mathrm{Ph}+\mathrm{Ks}$ & 66.08 & cdefg & 89.33 & abcde & 6.51 & $\mathrm{bcd}$ & 9.06 & abcde & 162.10 & defgh & .94 fghij & 0.331 & $a b$ & .360 & $\mathrm{a}$ \\
\hline $30 \mathrm{~m}^{3} \mathrm{CM}+\mathrm{P}_{1}+\mathrm{W} \cdot \mathrm{Ph}+\mathrm{K}(\mathrm{s}+\mathrm{f})$ & 75.20 & $\mathrm{ab}$ & 93.33 & $a b$ & 7.79 & $a b$ & 9.66 & $a b$ & 184.93 & $a b$ & $226.99 \mathrm{ab}$ & 0.311 & $\mathrm{~b}$ & 0.332 & $\mathrm{a}$ \\
\hline $30 \mathrm{~m}^{3} \mathrm{CM}+\mathrm{P}_{2}+\mathrm{Wt} \cdot \mathrm{Ph}+\mathrm{Ks}$ & 64.20 & $\mathrm{fg}$ & 85.66 & bcde & 6.38 & $\mathrm{bcd}$ & 8.83 & abcde & 163.32 & defgh & 219.01 bcde & 0.339 & $a b$ & 0.352 & $\mathrm{a}$ \\
\hline $30 \mathrm{~m}^{3} \mathrm{CM}+\mathrm{P}_{2}+\mathrm{Wt} \cdot P \mathrm{Ph}+\mathrm{K}(\mathrm{s}+\mathrm{f})$ & 65.13 & efg & 89.33 & abcd & 6.57 & $\mathrm{bcd}$ & 9.12 & abcde & 159.81 & cdefgh & 210.90 defgh & 0.333 & $a b$ & 0.347 & $\mathrm{a}$ \\
\hline $30 \mathrm{~m}^{3} \mathrm{CM}+\mathrm{F}$ & 65.26 & defg & 84.00 & cde & 6.80 & $\mathrm{bcd}$ & 8.41 & cde & 169.92 & cdefgh & 219.80 bcde & 0.337 & $a b$ & 0.364 & $a$ \\
\hline $30 \mathrm{~m}^{3} \mathrm{CM}+\mathrm{P}_{2}+\mathrm{W} \cdot \mathrm{Ph}+\mathrm{K}(\mathrm{s}+\mathrm{f})$ & 78.01 & $a$ & 95.66 & $\mathrm{a}$ & 8.65 & $\mathrm{a}$ & 9.74 & $\mathrm{a}$ & 187.31 & $a$ & 213.17 & 0.303 & $\mathrm{~b}$ & 0.317 & $\mathrm{a}$ \\
\hline $30 \mathrm{~m}^{3} \mathrm{CM}+\mathrm{P}_{3}+$ Wt.Ph+Ks & 71.02 & abcdef & 86.00 & bcde & 6.72 & $\mathrm{bcd}$ & 8.52 & bcde & 167.30 & defgh & 215.85 cdef & 0.343 & $a b$ & 0.347 & $\mathrm{a}$ \\
\hline $30 \mathrm{~m}^{3} \mathrm{CM}+\mathrm{P}_{3}+\mathrm{Wt} \cdot P h+\mathrm{K}(\mathrm{s}+\mathrm{f})$ & 71.05 & abcdef & 88.66 & abcd & 6.50 & $\mathrm{bcd}$ & 8.81 & abcde & 166.92 & cdefgh & 220.54 bcde & 0.342 & $a b$ & 0.349 & $\mathrm{a}$ \\
\hline $30 \mathrm{~m}^{3} \mathrm{CM}+\mathrm{P}_{3}+\mathrm{W} \cdot \mathrm{Ph}+\mathrm{Ks}$ & 70.92 & abcdef & 89.33 & abcd & 7.19 & abcd & 9.12 & abcde & 174.80 & abcd & 215.40 cdef & 0.327 & $a b$ & 0.341 & $\mathrm{a}$ \\
\hline $30 \mathrm{~m}^{3} \mathrm{CM}+\mathrm{P}_{3}+\mathrm{W} \cdot \mathrm{Ph}+\mathrm{K}(\mathrm{s}+\mathrm{f})$ & 69.72 & colefg & 88.33 & abcd & 7.21 & abcd & 9.00 & abcde & 171.41 & abcdef & $223.06 \quad a b c$ & 0.339 & $\mathrm{ab}$ & 0.346 & $\mathrm{a}$ \\
\hline
\end{tabular}

$30 \mathrm{~m}^{3} \mathrm{CM}+\mathrm{P}_{3}+\mathrm{W} \cdot \mathrm{Ph}+\mathrm{K}(\mathrm{s}+\mathrm{f})$

CM

Wh

Cattle

$P_{1} \quad 25 \mathrm{~kg} / \mathrm{fed} \mathrm{P}_{2} \mathrm{O}_{5}$

$\mathrm{P}_{2} \quad 50 \mathrm{~kg} / \mathrm{fed} \mathrm{P}_{2} \mathrm{O}_{5}$

$\mathrm{P}_{3} \quad 75 /$ fed kg $\mathrm{P}_{2} \mathrm{O}_{5}$

Wt.Ph Without

phosphorien W.Ph $\begin{gathered}\text { With } \\ \text { phosphorien }\end{gathered}$

Ks

$72 \mathrm{~kg} / \mathrm{fed} \mathrm{K}_{2} \mathrm{O}$ (soil fertilization) $\mathrm{K}(\mathrm{s}+\mathrm{f}) \quad 60 \mathrm{~kg} \mathrm{~K} \mathrm{~K}_{2} \mathrm{O} / \mathrm{fed}$ (soil fertilization $+1 \%$ $\mathrm{K}_{2} \mathrm{O}$ /fed foliar fertilization) 


\section{El - Gazar, T. M. et al.}

Table 2: Bulb diameter, bulbing ratio at 160 days after planting, weight of bulb and bulb yield (ton/fed) of garlic as affected by combination among cattle manure, phosphorus levels, phosphorien and potassium fertilizer at harvest during $2003 / 2004$ and $2004 / 2005$ seasons.

\begin{tabular}{|c|c|c|c|c|c|c|c|c|c|c|c|c|c|c|c|c|}
\hline \multirow{3}{*}{\begin{tabular}{|l} 
Characters \\
$20 \mathrm{~m}^{3} \mathrm{CM}+\mathrm{P}_{1}+\mathrm{Wt} . \mathrm{Ph}+\mathrm{Ks}$ \\
\end{tabular}} & \multicolumn{4}{|c|}{ Bulb diameter $(\mathbf{c m})$} & \multicolumn{4}{|c|}{ Bulbing ratio } & \multicolumn{4}{|c|}{ weight of bulb (g) } & \multicolumn{4}{|c|}{ Bulb yield (ton/fed) } \\
\hline & \multicolumn{2}{|c|}{$2003 / 2004$} & \multicolumn{2}{|c|}{$2004 / 2005$} & \multicolumn{2}{|c|}{$2003 / 2004$} & \multicolumn{2}{|c|}{$2004 / 2005$} & \multicolumn{2}{|c|}{$2003 / 2004$} & \multicolumn{2}{|c|}{$2004 / 2005$} & \multicolumn{2}{|c|}{$2003 / 2004$} & \multicolumn{2}{|c|}{$2004 / 2005$} \\
\hline & 4.83 & j & 6.04 & j & 0.184 & & 0.237 & $\mathrm{a}$ & 73.79 & hi & 64.66 & $\mathrm{~g}$ & 8.173 & $\mathrm{~g}$ & 9.532 & $j$ \\
\hline $20 \mathrm{~m}^{3} \mathrm{CM}+\mathrm{P}_{1}+\mathrm{Wt} \cdot \mathrm{Ph}+\mathrm{K}(\mathrm{s}+\mathrm{f})$ & 4.89 & i) & 6.09 & ij & 0.184 & $a$ & 0.227 & $a b$ & 74.74 & ghi & 66.44 & $\mathrm{fg}$ & 8.266 & $\mathrm{fg}$ & 9.861 & hi \\
\hline $20 \mathrm{~m}^{3} \mathrm{CM}+\mathrm{P}_{1}+\mathrm{W} \cdot \mathrm{Ph}+\mathrm{Ks}$ & 4.91 & hij & 6.09 & hij & 0.185 & $\mathrm{ab}$ & 0.227 & $a b$ & 76.71 & efghi & 67.78 & efg & 8.603 & efg & 10.305 & ghi \\
\hline $20 \mathrm{~m}^{3} \mathrm{CM}+\mathrm{P}_{1}+\mathrm{W} \cdot \mathrm{Ph}+\mathrm{K}(\mathrm{s}+\mathrm{f})$ & 4.92 & hij & 6.10 & hij & 0.177 & $a b$ & 0.224 & $a b$ & 77.00 & defghi & 69.67 & cdefg & 9.221 & cdefg & 11.360 & Def \\
\hline $20 \mathrm{~m}^{3} \mathrm{CM}+\mathrm{P}_{2}+\mathrm{Wt} \cdot \mathrm{Ph}+\mathrm{Ks}$ & 92 & hij & 6.12 & hij & 0.175 & $\mathrm{ab}$ & 0.226 & $a b$ & 73.48 & & 68.55 & defg & 8.791 & defg & 0.762 & Efgh \\
\hline $20 \mathrm{~m}^{3} \mathrm{CM}+\mathrm{P}_{2}+\mathrm{Wt} . \mathrm{Ph}+\mathrm{K}(\mathrm{s}+\mathrm{f})$ & 94 & ghij & 6.15 & ghij & 0.174 & $\mathrm{ab}$ & 0.221 & $a b$ & 78.07 & cdefghi & 69.67 & cdefg & 9.257 & cdefg & 1.469 & Bcdef \\
\hline $20 \mathrm{~m}^{3} \mathrm{CM}+\mathrm{P}_{2}+\mathrm{W} \cdot \mathrm{Ph}+\mathrm{Ks}$ & 68 & $\mathrm{k}$ & 6.18 & $\mathrm{k}$ & 0.180 & $\mathrm{ab}$ & 0.219 & $\mathrm{ab}$ & 79.08 & cdefghi & 73.55 & bcdef & 9.412 & bcdef & 48 & Cdef \\
\hline $20 \mathrm{~m}^{3} \mathrm{CM}+\mathrm{P}_{2}+\mathrm{W} \cdot \mathrm{Ph}+\mathrm{K}(\mathrm{s}+\mathrm{f})$ & 5.04 & defgh & 6.19 & defgl & 0.165 & $\mathrm{ab}$ & & $\mathrm{ab}$ & 78.42 & cdefghi & 72.77 & bcdefg & 9.550 & bcdefg & 03 & Efg \\
\hline $20 \mathrm{~m}^{3} \mathrm{CM}+\mathrm{P}_{3}+\mathrm{Wt} \cdot \mathrm{Ph}+\mathrm{K}$ & 5.06 & defgh & 6.21 & defgh & 0.162 & $a b$ & & Th & 76.79 & efghi & 75.11 & abcde & 9.726 & abcde & & Efgh \\
\hline $20 \mathrm{~m}^{3} \mathrm{CM}+\mathrm{P}_{3}+\mathrm{Wt} \cdot \mathrm{Ph}+\mathrm{K}(\mathrm{s}+\mathrm{f})$ & 5.06 & defgh & 6.41 & defgh & 0.153 & $\mathrm{ab}$ & 0.196 & $a b$ & 83.34 & bcde & 80.78 & $\mathrm{ab}$ & 9.895 & $\mathrm{ab}$ & 12.372 & $A b c$ \\
\hline $20 \mathrm{~m}^{3} \mathrm{CM}+\mathrm{P}_{3}+\mathrm{W} . \mathrm{Ph}+\mathrm{Ks}$ & 5.26 & $a b c$ & 6.18 & $a b c$ & 0.148 & $\mathrm{ab}$ & 0.214 & $\mathrm{ab}$ & 83.82 & bcd & 77.33 & $a b c$ & 11.297 & $\mathrm{abc}$ & 10.592 & Fgh \\
\hline $20 \mathrm{~m}^{3} \mathrm{CM}+\mathrm{P}_{3}+\mathrm{W} \cdot \mathrm{Ph}+\mathrm{K}(\mathrm{s}+$ & 5.17 & & 6.37 & & 0.153 & $\mathrm{~b}$ & & & 83.74 & $\mathrm{bcd}$ & 76.88 & abcd & 10.921 & abcd & 12.305 & Abcd \\
\hline $30 \mathrm{~m}^{3} \mathrm{C}$ & 5.08 & & 6.20 & defg & 0.159 & $\mathrm{ab}$ & & & 80.41 & defgh & 76.77 & abcd & 10.409 & $a b c d$ & 10.608 & $\mathrm{Fgh}$ \\
\hline $30 \mathrm{~m}^{3} \mathrm{CM}+\mathrm{P}_{1}+\mathrm{Wt} \cdot \mathrm{Ph}+\mathrm{K}(\mathrm{s}+$ & 5.09 & defg & 6.22 & defg & 0.161 & $\mathrm{ab}$ & 0.2 & $\mathrm{ab}$ & 78.77 & cdefghi & 78.11 & $a b c$ & 10.496 & $a b c$ & 10.896 & Efg \\
\hline $\mathrm{P}_{1}+\mathrm{W} \cdot \mathrm{Ph}+\mathrm{Ks}$ & 5.31 & $a b$ & 6.2 & $a b$ & 57 & $a b$ & & & 76.00 & fghi & 73.11 & bcdef & 9.641 & bcdef & 10.557 & fgh \\
\hline $\mathrm{P}_{1}+\mathrm{W} \cdot \mathrm{Ph}+\mathrm{K}(\mathrm{s}+$ & 5.19 & $\mathrm{bcd}$ & 6.44 & $\mathrm{bcd}$ & 0.148 & $\mathrm{~b}$ & 0.192 & $\mathrm{ab}$ & 89.92 & $\mathrm{ab}$ & 82.55 & $\mathrm{a}$ & 11.437 & $\mathrm{a}$ & 12.448 & $\mathrm{Ab}$ \\
\hline$+\mathrm{P}_{2}+\mathrm{Wt} . \mathrm{Ph}+\mathrm{Ks}$ & 4.98 & fghi & 6.2 & fghi & 0 & $a b$ & & & 80.62 & cdefgh & 75.77 & abcde & 10.169 & abcde & 11.497 & Bcdef \\
\hline$+W t . P h_{t}$ & 4.95 & ghij & 6. & 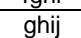 & 0. & $a b$ & & $\mathrm{ab}$ & 81.59 & cdefg & 70.11 & cdefg & 9.756 & cdefg & & Abcd \\
\hline $\mathrm{P}_{2}+\mathrm{W} \cdot \mathrm{Ph}+\mathrm{K}$ & 5.02 & efghi & 6.2 & efghi & 0.166 & $\mathrm{ab}$ & 0. & do & 82.76 & cdef & 70.66 & cdefg & 10.052 & cdefg & 5 & Def \\
\hline $\mathrm{m}^{3} \mathrm{CM}+\mathrm{P}_{2}+\mathrm{W} \cdot \mathrm{Ph}+\mathrm{K}$ & 5.38 & 3 & 6.4 & $\mathrm{a}$ & 0.136 & $\mathrm{~b}$ & & $\mathrm{~b}$ & 90.63 & $\mathrm{a}$ & 82.88 & $\mathrm{a}$ & 12.227 & $\mathrm{a}$ & 12.687 & A \\
\hline $0 \mathrm{~m}^{3} \mathrm{CM}+\mathrm{P}_{3}+\mathrm{Wt} . \mathrm{Ph}+\mathrm{K}$ & 5.08 & $\frac{a}{\operatorname{defg}}$ & 6.32 & defg & 0.162 & $\mathrm{ab}$ & 0.204 & $a b$ & 83.40 & bcde & 80.22 & $\frac{a}{a b}$ & 10.283 & $a b$ & 11.683 & Bcde \\
\hline $0 \mathrm{~m}^{3} \mathrm{CM}+\mathrm{P}_{3}+\mathrm{Wt} \cdot \mathrm{Ph}+\mathrm{K}(\mathrm{s}+\mathrm{f})$ & 5.09 & defg & 6.31 & defg & 0.164 & $\mathrm{ab}$ & 0.205 & $u_{n}$ & 84.00 & $\mathrm{bc}$ & 75.22 & abcde & 10.247 & abcde & 11.407 & Cdef \\
\hline $30 \mathrm{~m}^{3} \mathrm{CM}+\mathrm{P}_{3}+\mathrm{W} \cdot \mathrm{Ph}+\mathrm{K}$ & 5.11 & def & 6.38 & def & 0.167 & $\mathrm{ab}$ & 0.198 & $\mathrm{ab}$ & 84.86 & $a b c$ & 76.66 & abcd & 10.809 & abcd & 12.288 & Abcd \\
\hline $30 \mathrm{~m}^{3} \mathrm{CM}+\mathrm{P}_{3}+\mathrm{W} \cdot \mathrm{Ph}+\mathrm{K}(\mathrm{s}+\mathrm{f})$ & 5.06 & defgh & 6.31 & defgh & 0.166 & $a b$ & 0.201 & $a b$ & 84.16 & $\mathrm{bc}$ & 76.66 & $\mathrm{abcd}$ & 10.676 & $\mathrm{abcd}$ & 12.117 & Abcd \\
\hline
\end{tabular}

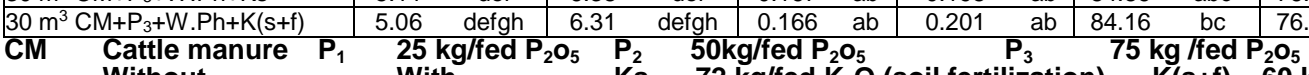

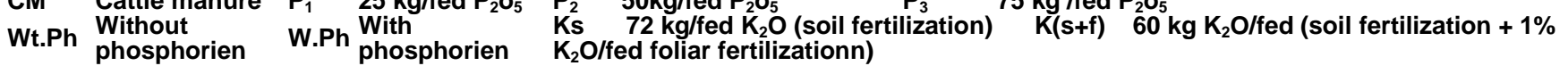


Table 3: Total chlorophyll at 120 days after planting, the percentage of $\mathbf{N}, P$ and $K$ in cloves of garlic as affected by combination among cattle manure, phosphorus levels, phosphorien and potassium fertilizer at harvest during 2003/2004 and 2004/2005 seasons.

\begin{tabular}{|c|c|c|c|c|c|c|c|c|c|c|c|c|c|c|c|c|}
\hline \multirow{3}{*}{\begin{tabular}{|l|} 
Treatments \\
$20 \mathrm{~m}^{3} \mathrm{CM}+\mathrm{P}_{1}+\mathrm{Wt} . \mathrm{Ph}+\mathrm{Ks}$ \\
\end{tabular}} & \multicolumn{4}{|c|}{ Total chlorophyll mg/g.f.w. } & \multicolumn{4}{|c|}{$\mathbf{N} \%$} & \multicolumn{4}{|c|}{$\mathbf{P} \%$} & \multicolumn{4}{|c|}{$\mathrm{K} \%$} \\
\hline & \multicolumn{2}{|c|}{$2003 / 2004$} & \multicolumn{2}{|c|}{$2004 / 2005$} & \multicolumn{2}{|c|}{$2003 / 2004$} & \multicolumn{2}{|c|}{$2004 / 2005$} & \multicolumn{2}{|c|}{ 2003/2004 } & \multicolumn{2}{|c|}{$2004 / 2005$} & \multicolumn{2}{|c|}{ 2003/2004 } & \multicolumn{2}{|c|}{$2004 / 2005$} \\
\hline & 0.351 & cdef & 0.284 & $\mathrm{a}$ & 2.45 & $\mathrm{k}$ & 3.54 & $\mathrm{ab}$ & 0.36 & $\mathrm{fg}$ & 0.33 & $\mathrm{ab}$ & 1.37 & $\mathrm{bc}$ & 2.15 & ef \\
\hline $20 \mathrm{~m}^{3} \mathrm{CM}+\mathrm{P}_{1}+\mathrm{Wt} \cdot \mathrm{Ph}+\mathrm{K}(\mathrm{s}+\mathrm{f})$ & 0.375 & bcdef & 344 & & 2.49 & $\mathrm{jk}$ & 4.25 & $\mathrm{a}$ & 0.34 & $g$ & 0.34 & $\mathrm{ab}$ & 1.65 & $\mathrm{abc}$ & 2.15 & ef \\
\hline $20 \mathrm{~m}^{3} \mathrm{CM}+\mathrm{P}_{1}+\mathrm{W} \cdot \mathrm{Ph}+\mathrm{Ks}$ & 0.327 & def & 0.286 & $\mathrm{a}$ & 2.64 & & 4.20 & $u_{i}$ & 0.34 & $\mathrm{~g}$ & 0.35 & $a b$ & 1.40 & $\mathrm{bc}$ & 2.17 & def \\
\hline V.Ph+K(s+f) & 0276 & ef & 0 & & 2.97 & $\mathrm{i}$ & 3.9 & $a b$ & 0.38 & efg & & $a b$ & 1.47 & $a b c$ & 2.22 & cdef \\
\hline Vt.Ph+Ks & & cdef & & & 3.24 & $\mathrm{~h}$ & 3.59 & $a b$ & 0.39 & defg & & $a b$ & 1.62 & $a b c$ & 2.07 & f \\
\hline Wt.Ph+K(s+f) & & bcde & 0 & $a$ & 3.28 & gh & 3.8 & $\mathrm{ab}$ & 0.43 & bcdefg & 0.42 & $a b$ & 1.37 & $\mathrm{bc}$ & 2.15 & ef \\
\hline V.Ph+1 & & $f$ & & 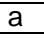 & 3.58 & bcde & 3.68 & $a b$ & 0.41 & bcdefg & 0.43 & $a b$ & 1.40 & $\mathrm{bc}$ & 2.40 & bcde \\
\hline$+f)$ & & def & & & 3.54 & cdef & 4.25 & $\mathrm{a}$ & 0.39 & defg & 0.43 & $a b$ & 1.55 & $a b c$ & 2.12 & ef \\
\hline Vt.Ph+ & 0. & bcdef & 0.2 & $\frac{a}{a}$ & 3.45 & defg & 3.73 & $\mathrm{ab}$ & 0.40 & cdefg & 0.41 & $a b$ & 1.30 & $\mathrm{c}$ & 2.12 & ef \\
\hline Nt.Ph+K(s+f) & & bcdef & & & 3.26 & $\mathrm{gh}$ & 4.30 & $\mathrm{a}$ & 0.49 & abcd & & -5 & 1.50 & $a b c$ & 2.40 & abcde \\
\hline $\mathrm{PPh}+$ & & $a b c$ & & $a$ & 3.5 & bcde & 3.83 & $\mathrm{ab}$ & 0.42 & bcdefg & 0. & 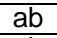 & 1.32 & $\mathrm{C}$ & 2.32 & bcdef \\
\hline$+K(s+f)$ & 0.3 & def & & $\mathrm{a}$ & 3.5 & bcde & 3.9 & $\mathrm{ab}$ & 0.46 & abcdef & & $\mathrm{a}$ & 1.32 & $\mathrm{C}$ & 2.35 & abcdef \\
\hline 5 & & cdef & & $\mathrm{a}$ & 3.3 & fgh & 3.6 & $a b$ & 0.43 & bcdefg & & $\bar{a}$ & 1.45 & $\mathrm{abc}$ & 2.57 & $\mathrm{ab}$ \\
\hline Nt.Ph+K(s+f) & & def & & $\mathrm{a}$ & 3.29 & gh & 4.20 & 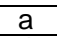 & 0.42 & bcdefg & 0.38 & $\mathrm{ab}$ & 1.40 & $\mathrm{bc}$ & 2.45 & abcd \\
\hline$\overline{N P h+K s}$ & & def & & $\bar{a}$ & 3.3 & efgh & 3.59 & $\mathrm{ab}$ & 0.44 & bcdefg & & $\mathrm{ab}$ & 1.50 & $a b c$ & 2.40 & abcde \\
\hline$s+f)$ & & $a b$ & & a & 3.7 & $a b c$ & 3.73 & $\mathrm{ab}$ & 0.51 & $a b$ & 0. & $a b$ & 1.70 & $a b c$ & 2.22 & cdef \\
\hline$\ldots$ & 0. & bcde & & & 3.6 & $a b c$ & 3.92 & at & 0.41 & bcdefg & 0. & $\mathrm{al}$ & 1.50 & $a b c$ & 2.47 & $a b c$ \\
\hline$(s+f)$ & & bcde & & $\mathrm{a}$ & 3.7 & $a b c$ & 3.83 & $\mathrm{a}$ & 0.4 & cdefg & & $\mathrm{al}$ & & $a b c$ & 2.40 & abcde \\
\hline & 0.4 & abcd & 0.249 & $\mathrm{a}$ & 3.7 & $a b c$ & 3.87 & $a b$ & 0.45 & abcdef & 0.32 & $\mathrm{~b}$ & 1.62 & $a b c$ & 2.35 & abcdef \\
\hline$s+f)$ & & $a$ & 0.4 & $\mathrm{a}$ & 3.8 & anc & 4.25 & $\mathrm{a}$ & 0.55 & socis & 0. & $\mathrm{ab}$ & 1.82 & $\mathrm{a}$ & 2.40 & abcde \\
\hline $0 \mathrm{r}$ & 0.4 & bcd & 0.256 & $a$ & $3.7 €$ & $a b$ & 3.44 & $a b$ & 0.50 & $a b c$ & 0.48 & a & 1.71 & $a b c$ & 2.32 & bcdef \\
\hline$(s+f)$ & 0.321 & def & 0.313 & $u$ & 3.73 & $a b c$ & 4.01 & $\mathrm{a}$ & 0.47 & abcde & 0.39 & $\mathrm{al}$ & 1.77 & $a b$ & 2.27 & cdef \\
\hline W.Ph+Ks & 0.282 & ef & 0.284 & $\mathrm{a}$ & 3.75 & $a b c$ & 3.78 & $\mathrm{ab}$ & 0.48 & abcde & 0.4 & $a b$ & 1.50 & $a b c$ & 2.62 & $\mathrm{a}$ \\
\hline$+W \cdot P h+K(s+f)$ & 0001 & ef & 0.293 & & 3.64 & abcd & 4.35 & 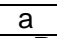 & 0.44 & bcdefg & 0.39 & $a b$ & 1.43 & $a b c$ & 2.30 & cdef \\
\hline
\end{tabular}

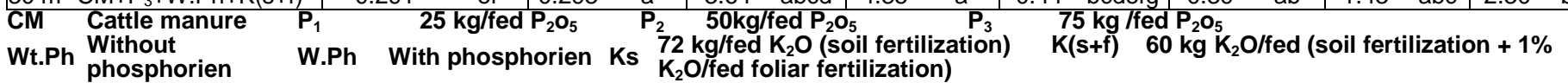


El - Gazar, T. M. et al. 